Science, Technology and Development 35 (1): 6-15, 2016

ISSN 0254-6418 / DOI: 10.3923/std.2016.6.15

(C) 2016 Pakistan Council for Science and Technology

\title{
Analysis of Management Support and Teaching Practices for the Implementation of New Elementary Science Curriculum in Islamabad Model Schools
}

\author{
${ }^{1}$ Amina Noor, ${ }^{2}$ Qudsia Rifat and ${ }^{3}$ Afshan Huma \\ ${ }^{1}$ National Institute of Science and Technical Education (NISTE), Islamabad, Pakistan \\ ${ }^{2}$ Department of Science Education, Allama Iqbal Open University, Islamabad, Pakistan \\ ${ }^{3}$ Education Planning and Policy Studies (EPPS), Allama Iqbal Open University, Islamabad, Pakistan
}

\begin{abstract}
This descriptive study aimed at exploring the teaching practices of elementary science teachers and the support provided by the management of 80 Islamabad Model Schools, after introducing new textbooks based on science curriculum 2006. The curriculum enforces the dissemination of content through student centered and inquiry based teaching approach for conceptual development of the students. It is important because this approach facilitates students to understand the included themes of Science, Technology, Society and Environment in the textbooks and to make them able to integrate the scientific concepts in real life situations. In this respect, the data were taken from the schools' heads and science teachers through questionnaires, while some heads were also interviewed about the actual application of the curriculum. They also suggested ways to remove the hurdles regarding the improvement of science education. The correlated results were presented by analyzing the effects of the school's profile, the teacher's profile and the support of management on the practices of the science curriculum. The positive values are seen in some of the practices, which reflected the potential of teachers in pedagogical skills, while management support was often seen in the teaching of science contents. For this, they believed in the participation of teachers, parents, students and other schools and more often facilitate teachers for concept building of the students, but rarely recommended teachers for trainings. In the interview, they commented that the science teaching practices may be improved by teacher training, timely delivery of textbooks, available resources for the induction of dropout students and controlling school security threats.
\end{abstract}

Key words: Practices, curriculum, science technology society and environment, student centered and inquiry based, teaching

\section{INTRODUCTION}

Science is a way of understanding the physical universe. Using a scientific approach of observation and experimentation, the natural phenomena of the universe can be understood and explained. Over the past few decades, experiment and activity based teaching has become popular in schools from primary to higher level and has shown to be more effective in promoting the science education, Faize (2011) and Iqbal et al. (2009). However, in Pakistan, the quality of science education at every level is not up to the standards, that are required to meet the challenges of the 21st century. Science Curriculum (MoE., 2006), National Education Policy 2009, National Professional Standards for Teachers (2009) and Provincial Education Sector Plan 2013-18 are the major efforts to foster the intellectual competencies of the teachers and students. Different studies (Santrock, 2006; Barak and Shakman, 2008; Faize, 2011) and science education reforms (MoE., 2006, 2009a, 2010) have emphasized the need of this paradigm shift in science teaching from behaviourist to constructivist approach.

The National Curriculum for Elementary Science-Grade 4-8 advocates that the science teaching should be on constructivist approach that gets through: (1) Student centered, (2) Inquiry based and (3) Outcomes focused approach. The first two relate to science teaching and classroom practices to attain the outcomes of each grade. The third one focuses on Student Learning Outcomes (SLOs) giving concept-wise expectations for each grade. At the federal level, the science curriculum 2006, which is, practically in effect from 2010 together with the provision of textbooks at elementary and secondary level, gives the core concept of Student Centered and Inquiry Based (SCIB) approach for student development. It expects the promotion of students' knowledge construction as opposed to using a teacher-centered approach. This paradigm shift from traditional to inquiry approach is addressed by the 
Curriculum Benchmarks and SLOs, which are based on four (4) strands; knowledge, attitude, skill and Science, Technology, Society and Environment (STSE). For concrete tasks of teaching, the comprehensive guidelines for teaching practices and student assessment instructions are also given.

Different government institutions and international agencies are working and collaborating in the implementation of the SCIB approach in science teaching. Project of Japanese International Cooperation Agency (JICA) worked for the Promotion of Student Centered and Inquiry Based Science Education in Pakistan, from 2009 to 2012 and Canadian International Development Agency (CIDA) is working all over the country for the Capacity Building of Teacher Training Institutions and imparting teacher trainings. These efforts are made in the light of the National Curriculum for Elementary Level and performance indicators for teachers under a document titled National Standards for Professional Development of Teachers, 2009.

Theoretical framework: The teaching practices are considered to be the key area for educational development. The managerial responsibility is to review and appraise the existing standards and practices of teachers along with provision of resources. But most of the recent developments recommend changes in teaching methodology from teacher-centered to student-centered approach to enhance the applications of the inquiry-based teaching (Wenglinsky, 2001; Barak and Shakhman, 2008). In science teaching, teacher is becoming a major driver for capacity building of the students and a monitor to assess the required conditions for learning (based on behaviourism and/or for constructivism) mainly through lessons and student assessment. These learning approaches help the teachers to continually focus on their students' performance in the existing learning environment (Bryan and Abell, 1999; El-Deghaidy et al., 2015; Weimer, 2012; Zhu et al., 2013).

Teacher's role in science teaching: "Invest in the future, invest in teachers" was the theme of the UNESCO conference, 2014. This is a key message for every nation (Hakeem, 2014). In the real context, Dancy and Henderson (2007) said that "it is valid and useful, because a teacher might hold very progressive views about education, but may practice conservative teaching method. Such a situation could be a result of various factors, such as a teacher's lack of knowledge in the content, and/or pedagogical skill, difficulties in adapting to change, or pressure at school”. The teacher is an executor, who disseminates the standards of education. These standards demand explicit concepts in order to allow the students to reflect and examine as well as revisit the concept in a different context (Understanding Science). The teaching in Science is an inspiring process for both the teacher and students. It creates the natural curiosity and leads to scientific endeavours to understand the concepts. Due to the technological needs of learners, the teacher's role becomes multifaceted and his/her role shifts from class-manager to class-facilitator. There are some directions for teachers that the teaching strategies should relate to the outcomes of the science curriculum and be consistent with the teaching role to be adopted (National Elementary Science Curriculum, 2006). The curriculum advises teachers to adopt different procedures rather than teaching in the conventional style. It also recommends teachers to provide their students with an ample opportunity, "to propose, perform and evaluate solutions for problem solving or technological tasks or questions." By promoting the Science, Technology, Society and Environment strand (STSE), the teacher realizes that teaching, today, is not only for providing help in concept building, but also for helping them visualize higher-level thinking, which encourages the students to verify their learnt concepts in real life situations (National Elementary Science Curriculum, 2006).

Role of management in science teaching practices: School managers have realized the value of well-defined science practices required for teaching and for the development of students. They understand that the authority, responsibility and unity of direction are the organizational principles (Fayol's principles). The Fayol's Principles (1870s) that can be worked in both management and academic operations. He believed that the responsibility is a corollary of authority, while direction refers to "one head, one plan" for an effective action. Through this, the class manager's (teacher) and school manager's (head) thoughts and capabilities should be aligned to harmonize the system. The two big educational challenges; quantity, in terms of access and equity and quality of the learners and the learning process would also be met by the improvised system. For this the school management would promote the collaborative environment and initiate open discussion with teachers to attain the student-achievement goals, School Improvement in Maryland (2016). The technological advancement makes the education systems fast and innovative, which demands that managers emphasize on teachers' productivity and training. However, this perspective is also referred to by different researches that the performance of the institution is affected by the management's involvement and support in academic activities (Pakistan Education System Problems, 2014; Almazroa, 2014; Schieb and Karabenick, 2011). 
Teacher's training as an effective tool in improving teaching practices: Wenglinsky (2001) said that "if academic standards are rigorous, curriculum and assessment is aligned to those standards and teachers possess the skills to teach at the level the standards demand, student performance will improve". However, this perspective is related to the training of the teachers to improve the classroom practices and to understand the required standards for science curriculum. It is increasingly being recognized that the professional skills and teaching ability of the teacher is reflected through the use of learning instructions. Some of the practices recommended by different researchers for science teaching such as:

- Investigate the students' difficulties and rectify their misconceptions (Loughran et al., 2012; Miller, 2000)

- Promote hand-on activities and understand the scientific concepts through self-experiences (Wenglinsky and Silverstein, 2007)

- Fostering higher order thinking (Barak and Shakhman, 2008)

- Explore new learning concepts by self-study, (Whitehead, 2009)

- Reduce diversity in individuals by using varied teaching styles, etc. (Prince and Felder, 2006)

It was also recommended by Hakeem (2014), who mentioned that "the investment in teachers and quality teaching requires well trained teachers and a conducive learning and encouraging environment, as well as efficient use of teachers, particularly in disadvantaged areas, by offering incentives" (UNESCO conference, Islamabad). It emphasizes the learner-based trainings which execute the teachers' capabilities to plan the lessons, design the activities and foster higher cognitive thinking through teaching practices. The sophisticated knowledge for selection of subject matter and use of appropriate inquiry questions cannot be embedded in the curriculum and textbooks. The training sessions not only interpret the curriculum outcomes, but also explain the effect of selected learning material in different teaching situation. Teacher training is a professional development of teacher that would offer teachers new information on a particular aspect of their work. Villegas-Reimers (2003) said that "only in the past few years has the professional development of teachers has been considered a long-term process that includes regular opportunities and experiences planned systematically to promote growth and development in the profession (p.12)". This shift in teacher training has been referred as a new paradigm in teachers' education and intimately linked to school reforms.
For reforms in science education and training, various studies recommended the need of Pedagogical Science Knowledge (PSK) or Pedagogical Content Knowledge (PCK). It is a blended approach, which in an understanding of science content and representation, inquiry processes, inquiry analysis and communication, reflection and social implication. In addition, the teacher will acquire the knowledge of how children learn and skills for facilitating children's experiences for prompt active inquiry and conceptual development (Loughran et al., 2012; Chalufour, 2010). To embrace the quality teaching, the National Professional Standards for Teachers gave principles of continuous professional development in four main areas; acquisition of current and recent content knowledge of subject, use of instructional tools, strategies and pedagogical skills, ethical monitoring and assessing of student learning outcomes and cultivating in students the ethical scholarly dispositions (MoE., 2009b). For enforcing the quality education, the quality teaching practices are contingent, which can be achieved through continuous attention to the basic needs of teachers.

This study envisaged the current science teaching practices and management support for the dissemination of the new curriculum at the elementary level. In addition to that, the study also found some hurdles that affected the teaching-learning processes of Islamabad Model Schools especially during the academic session of 2014-15.

\section{MATERIALS AND METHODS}

The questionnaires were prepared, piloted and sent to 215 schools selected through random sampling, considering area and gender equality, in the month of December 2014. After analysis of the returned questionnaires, the valid responses came from 80 (37.2\%) schools that were incorporated into the study. The variations in the numbers of responses received from the schools did not allow for a comparison of teaching practices in the context of area (urban and rural) and gender (male and female teachers' practices) (Table 1). Hence, the overall teaching practices and support of management of different Islamabad Model Schools were evaluated through the survey to see the correlation between them.

For investigation of elementary science teaching practices, the heads' questionnaire contained four open ended questions, whereas teachers' questionnaire had 34 items, that were divided into the following main categories; School profile-3 items; Teacher profile-4 items; Teacher competencies-6 items; Teacher's Practices-11 items and Management support-10 items. These items related to the teacher's pedagogical 
Sci. Technol. Dev., 35 (1): 6-15, 2016

Table 1: Demographic distribution of school and elementary teachers in the study $(\mathrm{N}=80)$

\begin{tabular}{|c|c|c|c|c|c|}
\hline School variables & Category & Frequency & Percent & M & SD \\
\hline \multirow{2}{*}{ Area } & Urban & 38 & 47.5 & 1.53 & 0.503 \\
\hline & Rural & 42 & 52.5 & & \\
\hline \multirow[t]{2}{*}{ Gender } & Male & 18 & 22.5 & 1.22 & 0.420 \\
\hline & Female & 62 & 77.5 & & \\
\hline \multirow[t]{2}{*}{ Class-size } & Less than 50 & 54 & 67.5 & 1.32 & 0.471 \\
\hline & $51-70$ students & 26 & 32.5 & & \\
\hline Teacher variables & \multicolumn{5}{|c|}{ One teacher participated from each school ( 80 teachers, 38 from urban and 42 from rural schools) } \\
\hline \multirow[t]{2}{*}{ Specialization } & Science & 63 & 78.8 & 1.21 & 0.412 \\
\hline & Non science & 17 & 21.3 & & \\
\hline \multirow[t]{5}{*}{ Qualification } & Matric & 12 & 15.0 & 3.14 & 1.240 \\
\hline & F.Sc & 15 & 18.8 & & \\
\hline & B.Sc & 8 & 10.0 & & \\
\hline & Master & 37 & 46.2 & & \\
\hline & $\mathrm{PhD}$ & 8 & 10.0 & & \\
\hline \multirow[t]{3}{*}{ Professional Education } & $\mathrm{CT}$ & 8 & 10.0 & 2.22 & 0.653 \\
\hline & B.Ed & 40 & 50.0 & & \\
\hline & M.Ed & 32 & 40.0 & & \\
\hline \multirow[t]{3}{*}{ Experience } & Less than one year & 20 & 25.0 & 1.95 & 0.673 \\
\hline & $1-10$ years & 44 & 55.0 & & \\
\hline & 11 and above & 16 & 20.0 & & \\
\hline
\end{tabular}

M: Mean, SD: Standard deviation

Table 1a: Self-opinion of teachers on their own teaching competencies

\begin{tabular}{lcc}
\hline Competencies & M & SD \\
\hline Lesson plan preparation & 2.64 & 1.438 \\
Classroom management & 2.55 & 1.439 \\
Designing science activities & 2.64 & 1.446 \\
Designing inquiry questions & 2.04 & 1.037 \\
Guide other teachers & 1.97 & 1.144 \\
Self study & 2.13 & 1.184 \\
\hline
\end{tabular}

Scale: Competent 4- 3- 2- 1- 0 not competent

Table 2: Teachers' opinion about teaching practices in science classes labelled as (P1 to P11)

\begin{tabular}{|c|c|c|c|}
\hline & For effective implementation of new science textbook, science teachers; & $\mathrm{M}$ & SD \\
\hline$\overline{\mathrm{P} 1}$ & Communicate students' science difficulties and solve during class & 2.06 & 0.932 \\
\hline P2 & Motivate to participate in class activities & 1.91 & 0.860 \\
\hline P3 & Motivate students to discuss the topics among other students and present their points & 2.50 & 0.968 \\
\hline P4 & Encourage to take an interest in science inquiry based questions rather than traditional questions & 2.05 & 1.231 \\
\hline P5 & Assess continuously their misconception and rectify it & 2.38 & 0.986 \\
\hline P6 & Encourage self-study approach on assigned topics & 2.40 & 1.086 \\
\hline P7 & Promote to share understanding in peer & 2.45 & 1.211 \\
\hline P8 & Guide the students to feel responsible for creating a healthy environment in their vicinity & 1.81 & 0.982 \\
\hline P9 & Ask more examples from daily life & 1.36 & 0.661 \\
\hline P10 & Encourage students to understand learning expectation & 1.93 & 0.854 \\
\hline P11 & Promote to share scientific information with parents and others & 2.70 & 1.326 \\
\hline
\end{tabular}

Scale: 1: Never, 2: Rarely, 3: Often, 4: Occasionally, 5: Frequently

(P2, P3, P6, P7, P8, P11) and content teaching skills (P1, P4, P5, P9, P10), that were selected by studying the previous research articles and science curriculum 2006. The item-wise result of the questionnaires was analyzed, using the statistical package for social sciences (SPSS). The comprehensive detail is given in Table 1-3. Along with a mean (M) and Standard Deviation (SD), the teaching and management practices were also treated with Pearson product correlation coefficient at 2 -tailed test, presented by “ $\mathrm{r}$ ” values. The positive values show the variable rise and fall together, while a negative value shows the reciprocal relationship between variables. The correlated values are calculated in three contexts to see the relationship between two variables; effect of school's profile (area and class size) on teaching practices, the effect of teacher's profile (specialization, professional education and experience) and the effect of management support on teaching practices (Table 4-6).

The opinion of school heads was also investigated through a semi- structured interview with reference to the implementation of the science curriculum in elementary classes. The two questions were asked from 15 (18.7\%) heads: Is the SCIB theme of curriculum applicable in the context of a Pakistani classroom? And what are the hurdles that affect the teaching practice of the teachers and management for the improvement of science education? 
Sci. Technol. Dev., 35 (1): 6-15, 2016

Table 3: Teachers' opinion about management support for teaching science labelled as (M1 to M10)

\begin{tabular}{|c|c|c|c|}
\hline & For effective implementation of new science textbook, school management & $\mathrm{M}$ & SD \\
\hline M1 & Arranges awareness meeting for teachers, parents \& students & 3.15 & 1.406 \\
\hline M2 & Provides more appropriate material \& equipments & 2.55 & 1.282 \\
\hline M3 & Recommends teachers for subject training & 2.47 & 1.378 \\
\hline M4 & Assigns appropriate teacher(s) for teaching science & 2.19 & 1.342 \\
\hline M5 & Facilitates in concept building of students through & & \\
\hline M5.a & Free use of computer lab for teachers & 3.61 & 1.336 \\
\hline M5.b & Visits to exhibitions and science activities, when arranged & 3.65 & 1.313 \\
\hline M5.c & Invites more relevant experts on science topics, when needed & 2.88 & 1.344 \\
\hline M6 & Discusses teaching methodology on new contents with teachers & 3.10 & 1.437 \\
\hline M7 & Provides time (extra period) for students’ activity & 2.55 & 1.386 \\
\hline M8 & Listens to your views to solve academic problems & 2.56 & 1.241 \\
\hline M9 & Shares problems with other schools and higher authorities & 3.18 & 1.465 \\
\hline M10 & Discusses results with teachers and parents for betterment. & 3.04 & 1.479 \\
\hline
\end{tabular}

1: Never, 2: Rarely, 3: Often, 4: Occasionally, 5: Frequently

Table 4: School's Profile: Teaching practices at elementary science class $(\mathrm{N}=80)$

\begin{tabular}{|c|c|c|c|c|c|c|c|c|c|c|c|}
\hline \multirow[b]{2}{*}{ School Profile } & \multicolumn{11}{|c|}{ Teaching practices } \\
\hline & P1 & P2 & P3 & P4 & P5 & P6 & P7 & P8 & P9 & P10 & P11 \\
\hline Area & & & & $0.223 * *$ & $-0.275^{*}$ & & & & & & \\
\hline Class size & & & & $-0.268 *$ & $-0.238 *$ & 0.2 & & & & & $-0.288 * *$ \\
\hline
\end{tabular}

${ }^{*}$ Correlation is significant at 0.05 levels (2-trailed), ${ }^{* *}$ Correlation is significant at 0.01 levels (2-trailed)

Table 5: Teacher profile: Teaching practices at elementary science class $(\mathrm{N}=80)$

\begin{tabular}{|c|c|c|c|c|c|c|c|c|c|c|c|}
\hline \multirow[b]{2}{*}{ Teacher profile } & \multicolumn{11}{|c|}{ Teaching practices } \\
\hline & P1 & P2 & P3 & P4 & P5 & P6 & P7 & P8 & P9 & P10 & P11 \\
\hline Specialization & & $0.268 *$ & & & & & $-0.245^{*}$ & & $0.225^{*}$ & & \\
\hline Education & & $0.482^{* *}$ & $0.223^{*}$ & & & $0.369^{* *}$ & & $0.270^{*}$ & & & \\
\hline Experience & $0.517^{* *}$ & & $-0.287 * *$ & & $0.305^{* *}$ & & $0.464 * *$ & $0.383 * *$ & & & \\
\hline
\end{tabular}

${ }^{*}$ Correlation is significant at 0.05 levels (2-tailed), ${ }^{* *}$ Correlation is significant at 0.01 levels (2-tailed)

Table 6: Management Support: Teaching practices at elementary science class $(\mathrm{N}=80)$

\begin{tabular}{|c|c|c|c|c|c|c|c|c|c|c|c|c|}
\hline \multirow[b]{2}{*}{ Teachers' practices } & \multicolumn{12}{|c|}{ Management support } \\
\hline & M1 & M2 & M3 & M4 & M5a & M5b & M5c & M6 & M7 & M8 & M9 & M10 \\
\hline & P1 & & & & & & $0.225^{*}$ & & & & & \\
\hline & P2 & & & & & & & & & & & \\
\hline & P3 & & & & & & & & & & & \\
\hline & P4 & & & & & & $0.308^{* *}$ & $0.241^{*}$ & & & & \\
\hline & P5 & & & & & & & & & & & $0.225^{*}$ \\
\hline & P6 & & & & & & & & & & & \\
\hline & P7 & & & & & & & & & $0.220 *$ & & \\
\hline & P8 & & & & & & & & & & & \\
\hline & P9 & & $0.270^{*}$ & & & & & & & & & \\
\hline & P10 & & & & & & & & & & & \\
\hline & P11 & & & & & & & & & & & \\
\hline
\end{tabular}

*Correlation is significant at 0.05 levels (2-tailed), ${ }^{* *}$ Correlation is significant at 0.01 levels (2-tailed)

Table 1 shows that the sample of 80 schools (47.5\% urban and $52.5 \%$ rural) belonged to $22.5 \%$ male and $77.5 \%$ female schools. The class size of $67.5 \%$ schools was less than 50 students. According to the teacher's profile, $78.8 \%$ teachers teaching elementary classes had a science degree out of which $46.2 \%$ had a Masters degree, while also majoring in professional education (B.Ed or M.Ed). About 55\% teachers had one to 10 years of experience in teaching science.

The self-opinion of teachers on their own teaching competencies to deliver the science content was also taken and findings are reflected in Table 1a. The data revealed that the teachers' abilities in the preparation of lesson plan and designing the science-activities are better than the others competencies on the five point rating scale. It was also seen that they need special attention in designing the inquiry questions and time for self study, while guide other teachers on science concepts is also not the easiest task for them.

To understand the findings of the study, the items of the questionnaire are presented in Table 2 and 3. The data in these tables revealed that the management support mean- score range [1.46 (3.65-2.19)] is higher than teaching practices score range [1.34 (2.70-1.36)] regarding the teaching of science. 


\section{RESULTS AND DISCUSSION}

The result of the survey is presented in tabular form in three sections: (a) Effects of school's profile on teaching practices, (b) Effects of teacher's profile on teaching practices and (c) Effects of management support on teaching practices.

Effects of school's profile on teaching practices: The eleven items of teaching practices were correlated to probe the relation of teaching practices with school's profile, i.e., area (urban/rural schools) and class size (less than 50 students, 51 to 70 students and 71 and more) (Table 4). The school area and class size are the sensitive factors for effective science teaching practices and management. The corrections between school's profile and teacher practices were statistically significant in some of the practices such as P6 and P11, which are pedagogical skills, while P4 and P5 are the content teaching skill of the teachers. These indicate with weak coefficient values of " $+r$ " that means the characteristics of school profile and teaching practices are influenced each other directly or indirectly, due to a class size of more than 50 students in 26 (32.5\%) schools. But, it is also possible that these might be influenced by non- qualified teachers of 17 (21.3\%) schools.

Effects of teacher's profile on teaching practices: The study sought to examine the relationship between teaching practices with reference to the teacher's profile (Table 1), i.e., specialization, professional education and experience respectively. The result reveals in Table 5 that there were positive significant correlations, at $\mathrm{p}<0.05$ on teaching practices $\mathrm{P} 2$, P3, P6, P8 and P9, while negative significant correlations at $\mathrm{p}<0.05$ at $\mathrm{P} 4$ and $\mathrm{P} 7$. Out of eleven practices, only P4 (-r) and P9 (+r) are related to science content. The $\mathrm{P} 4$ shows the reciprocal relationship between teaching practice and teachers' experience, while, P9 practice has a direct relationship with the specialization and teaching experience of the teachers. The teachers' teaching limitations in this context were also seen in their competency profile (Table 1a), that predicts their training need and requirement for extensive self- study on the new concepts of the science curriculum.

Effects of management support on teaching practices: Table 6 shows the weak relationship, but positive coefficient values in five teaching practices out of 11 with six school management support practices. In the following cases, the results are significant at 0.01 and 0.05 levels and reflect as:
- $\quad$ Between M2 and P9, the management support through the learning material to identify more related science examples, $\mathrm{r}=+0.270$

- $\quad$ Between M5b and P1, the management arranged the study visits and activities for teachers and students, to reduce their difficulty of the science content, $r=+0.225$ at $\mathrm{p}<0.01$ level

- $\quad$ Between M5b and P4, the management arranged the study visits and activities for teachers and students, to enhance the interest in science, to understand higher cognitive inquiry questions, $r=+0.308$ at $\mathrm{p}<0.05$ levels

- $\quad$ Between M5c and P4, the management also invited science experts to create interest in science through inquiry questions, $\mathrm{r}=+0.241$ at $\mathrm{p}<0.01$ levels

- $\quad$ Between M7 and P7, the management provided extra time for performing science activities and sharing content for clarity of the concepts, $r=+0.220$ at $\mathrm{p}<0.01$ levels

- $\quad$ Between M10 and P5, the management was also prudent to share student results that might be affected by their misconception, $\mathrm{r}=+0.225$ at $\mathrm{p}<0.05$ levels

To sum up, it could be said that the improvement of science concepts, using the new curriculum, was the main priority of school management and they supported teacher's teaching practices, which are mainly related to the science contents rather than pedagogy.

Head's opinion on managerial requirements for science course: An open ended questionnaire was designed for school heads $(n=80)$, to solicit their views about science teaching practices and its implementation of new elementary science curriculum.

Availability of trained science teachers: About 63.7\% of the heads claimed to have trained teachers who got trainings from JICA and CIDA in-service elementary science teacher programs, however, $33.7 \%$ of the heads of rural areas also said that the highly qualified, trained teachers are working at the secondary level.

Difficulties in teaching science on SCIB approach: About $75 \%$ of the heads said that although the new science textbooks have been developed according to the new curriculum, but many new topics have the concepts of grade 9 and 10 level. Due to difficulty in comprehension experienced by the students; teachers avoid to teach on SCIB approach. The activities and portion of science, technology, society and the environment (STSE) are very useful, but difficult. Only 
young science teachers are motivated to use scientific techniques in the class. The $51.2 \%$ of the heads said that the Student Centered and Inquiry Based (SCIB) approach is applicable in classes, if they have provision of adequate learning materials and extra time, while the others did not answer the question. They also said that they encourage science teachers to develop activities and ask inquiry questions, but the examination system does not support the questions of higher cognitive level. Therefore, the reason, which causes deterioration of science education in schools, is the improper assessment of students. They also mentioned that due to the late delivery of textbooks, teachers have little time to work on SCIB approach. As a result, the library search and drafting of creative assignments after thorough study of the content are almost eliminated.

Utilization of trained teachers in in-house trainings: About $45 \%$ of the heads agreed to some extent that they have been able to conduct the in-house training programs. For that, a training resource, mechanism and the trainer are required, who should have training on content, pedagogy, science process skills and student assessments. The trainer should also be continuously monitored by the external trainers or officers from the Federal Directorate of Education. They (37.5\%) also suggested that there should be the separate and long duration training programs for junior and senior elementary teachers, so that they can continuously update their knowledge and skills according to their own pace.

Suggestions for science teacher training: One of the heads suggested that, "If the teachers are properly trained in content and assessment techniques, they would be able to improve the system by providing positive and constructive feedback to their students on their performance".

Most of the heads said that the training programs should be conducted in summer vacations or at the beginning of the academic session. The teachers should be nominated one month earlier so that the coursework could be adjusted. Some heads (27.5\%) recommended that the training institutions should give adequate weight-age to all course objectives and relate the concept to real life situations, provide online or off-line opportunities for learning as well as techniques to develop science resource material on various contents.

Analysis of teaching practices in the current scenario: $15(18.7 \%)$ school heads of IMS were interviewed and asked two questions about the application of the science curriculum and hurdles that affect the teaching practice of the teachers and management for the improvement of science education in the area.
It was found through discussion that according to the instructions of the Federal Directorate of Education (FDE), all heads are concerned with the school performance and achievement of student learning outcomes. During this year, the major issues were related to school security and induction of out of school children (OOSC). For security reasons, the reduction in the academic session took place and teachers emphasized on the completion of the course and preparation of final examination rather than working with hands-on activities in the class. On the other hand, Out of School Children (OOSC) (ASER, 2014), "Every child enrolls in school, Every child is retained in school, Every child learns and makes progress," admitted that despite the great efforts by the government to provide access and equity in education, schools fail to provide separate classes, extra time and resources to properly entertain the newly enrolled children.

The research also underpinned that SCIB teaching method requires sufficient time for group work in the class. The heads (71\%) realized that the science textbooks required activity based approach. The lessons are being developed by keeping pupils' ideas in focus and in the light of their prior knowledge. The content details and activities increase pupils' understanding. The students take interest in practicing those activities individually at home. Due to the short duration of class time, the teachers usually guide them and ask for results in the next class. While, some (42\%) heads realized that it was difficult for teachers to practice on SCIB approach this year. They (34\%) also stated that at the elementary level, there is provision of computers for teachers, but no facility for elementary students, but visits to school laboratory and discussions with senior teachers/experts were arranged for the clarity of concepts. For conceptual development of learners the creative questions are very important. For that the pattern of the examination system and setting of question papers should be aligned with classroom practices so that students' understandings and learnt skill could be assessed.

The heads suggested that the deficiencies in teaching practices would be improved by sharing results among teachers and discussing the academic problems among schools and higher authority for immediate solution. Here, teacher training institutions should play their role in the development of knowledge-driven system by introducing guidelines in different contexts.

In Pakistan, the educational departments are responsible for the dissemination of the school curriculum and implementation of its standards. The school head and teachers have a vital role in this respect. The teachers 
design the course work plan on the prescribed material to enhance the capacity and participation of the students in the class. While, the managerial services are responsible to monitor the teaching process as well as give suggestions for the creation of skills. Their main responsibility is to manage the resources and use them in time.

This study reveals that the management support is frequently providing all its resources for implementing science teaching practices on new curriculum in Islamabad Model Schools (IMS). School heads have mentioned that the reforms in science teaching need a significant mechanism for teacher professional development on science curriculum, the same was also supported by some studies (El-Deghaidy et al., 2015; Almazroa, 2014). By comparing the data, it is found that the schools as a whole encourage students to share scientific information with peers, parents and others. They believed in diversity of knowledge so that the participation of teachers and parents should be in connection with what the students are learning. The teachers' practices on pedagogical skills seemed better in making a student-centered class as compared to teaching skills for content. For instance; P1 (communicating students' science difficulties and solving their problems during class), is the only expelled practice. It shows no relationship in any school condition that would suggest that the teachers are updated on the new science curriculum. Some practices are supposed to be affected by rural school location, large class size of 51-70 students, as well as lack of teacher's specialization, qualification, professional education and teaching experiences.

With these concerns, the relationship between teaching practices and school management support practices were analyzed. The only six practices were correlated and shown with weak $+r$ values, out of them P1, P5 and P9 were presented the management support in science related activities. The other cases, where effective management practices are seen, include providing material and equipment, provision of extra time for the motivation of students in class activities and a search for more content related examples. It is also seen in the arrangement of visits for science activities that creates an interest in students and teachers. To encourage students to understand learning, teachers show their concerns and discuss with colleagues as well as other schools in the area.

The findings reflected that the science teaching practices and management support is not properly exercised in the schools as it should be. Van Der Krogt and Warmerdam (1997) said that the managers, so runs the conclusion, should strive to remedy such skill deficiencies. The analysis of the head's questionnaire and their interviews also described some of the teaching deficiencies in the current situation. It revealed that the government introduced the student enrolment policy based on Millennium Development Goal (MDG), by which the individual differences are created in each class due to their age and learning ability. The government recommended the separate set up for fresh students, but this mechanism could not be worked out due to limited resources in the public schools. This year, the schools also suffered from security threats which reduced the academic session and they were mainly concerned to cover the course.

Assessment is the tool to judge the teacher, teaching material and the student at the same time (Nicol and Macfarlane-Dick, 2006). The data revealed that the heads realize the importance of assessment for promoting the SCIB approach in teaching, but the limited flexibility was seen in its implementation due to uncertainty in the government policies and in the availability of the resources. Similarly, student assessment does not support the SCIB and it is still based on rote memorization of the concept, whether it is being taught in the class or assessed in the annual examination. The shortcoming in designing the inquiry questions is also seen in some of the replies of teachers at Table $1 \mathrm{a}$ and 2 particularly in delivering practices of $\mathrm{P} 1, \mathrm{P} 4$ and $\mathrm{P} 9$. The study suggested that these problems can be overcome by continues practicing SCIB approach in class teaching and teacher training programs. According to Barak and Shakhman (2008), further work is required in teachers' pre-service and in-service training to make the fostering of higher-order thinking a common ingredient in science teaching.

\section{CONCLUSION}

Schools' heads and teachers are utilizing all available resources and doing their best to practice the new elementary science curriculum. However, teachers require regular opportunities to deepen and expand their subject matter knowledge and skills through proper training and management support. The school heads are concerned for promoting and practicing student centered and inquiry based approach in science classes, but more focused for content activities and learners' development. In addition to that, delay in delivery of textbooks, inadequate resources for the induction of dropout students and controlling school security threats are the main causes which disturbed the attention of the teachers in practicing science skills.

Based on the findings of the study, it is recommended that school administrators and teachers should put emphasis on students' learning outcomes designed in science curriculum. In this context, familiarization with 
the curriculum guidelines is the major need for teachers and school heads. The in-service teacher training programs are the tool to envisage all the required perspective and practices, so link it according to the science content expectations and standards.

The system can function with the cooperation among stakeholders. The interactive networking between heads, teachers, parents, students, community members as well as experts of teacher training institutions should be encouraged in this context. This will help in focusing on school mission, expectations for success, academic performance and community role as well as the safety and orderliness of schools.

The researchers would like to thank NISTE officers (Ms. Sumaira, SCO, Mr. Imran, STO, Mr. Irfan-Ullah, STO, Mr. Kamran, STO), who shared their ideas and experiences with them and participated and facilitated in the data collection.

\section{REFERENCES}

ASER., 2014. Annual status of education report ASERPakistan 2013. Annual Status of Education Report, January 16, 2014. http://www.aserpakistan.org/ document/aser/2013/reports/national/ASER_Nation al_Report_2013.pdf

Almazroa, H., 2014. Professional development: A vision for Saudi science teachers. http://www.esera.org/ media/esera2013/Hiya_Almazroa_13\%20Feb2014. pdf

Barak, M. and L. Shakhman, 2008. Reform-based science teaching: Teacher's instructional practices and conceptions. Eur. J. Math. Sci. Technol. Edu., 4: 11-20.

Bryan, L.A. and S.K. Abell, 1999. Development of professional knowledge in learning to teach elementary science. J. Res. Sci. Teach., 36: 121-139.

Chalufour, I., 2010. Learning to teach science: Strategies that support teacher practice. ECRP, Seed Papers, May 2010, Iowa, USA. http://ecrp.illinois.edu/ beyond/seed/Chalufour.html.

Dancy, M. and C. Henderson, 2007. Framework for articulating instructional practices and conceptions. Phys. Rev. Special Top.: Phys. Edu. Res., 3. 10.1103/PhysRevSTPER.3.010103

El-Deghaidy, H., N. Mansour, A. Aldahmash and S. Alshamrani, 2015. A framework for designing effective professional development: Science teachers' perspectives in a context of reform. Eur. J. Math. Sci. Technol. Edu., 11: 1579-1601.
Faize, F.A., 2011. Problems and prospects of science education at secondary level in Pakistan. Ph.D. Thesis, Department of Education, Faculty of Social Sciences, International Islamic University, Islamabad.

Hakeem, A., 2014. Investing in quality education and teachers crucial to progress and a better society. UNESCO Islamabad Press Release. http:// unesco.org.pk/education/documents/2014/wtd/Pres s_Release.pdf

Iqbal, H.M., S. Azam and R.A. Rana, 2009. Secondary school science teachers' views about the nature of science. Bull. Edu. Res., 31: 29-44.

Loughran, J., A. Berry and P. Mulhall, 2012. Understanding and Developing Science Teachers' Pedagogical Content Knowledge. 2nd Edn., Springer, New York, USA., ISBN: 9789460918216 , Pages: 235.

Miller, K.F., 2000. Representational tools and conceptual change: The young scientist's tool kit. J. Appl. Dev. Psychol., 21: 21-25.

MoE., 2006. National elementary science curriculum, 2006. Ministry of Education, Government of Pakistan, Islamabad.

MoE., 2009a. National education policy 2009. Ministry of Education, Government of Pakistan, Islamabad. Revised August 01, 2009.

MoE., 2009b. National professional standards for teachers in Pakistan: Policy and planning wing, Government of Pakistan. Ministry of Education, Pakistan.

MoE., 2010. National education policy 1998-2010. Ministry of Education, Government of Pakistan, Islamabad, Pakistan.

Nicol, D.J. and D. Macfarlane-Dick, 2006. Formative assessment and self regulated learning: A model and seven principles of good feedback practice. Stud. Higher Edu., 31: 199-218.

Prince, M.J. and R.M. Felder, 2006. Inductive teaching and learning methods: Definitions, comparisons and research bases. J. Eng. Edu., 95: 123-138.

Santrock, J.W., 2006. Educational Psychology. 2nd Edn., McGraw-Hill, New York.

Schieb, L.J. and S.A. Karabenick, 2011. Teacher motivation and professional development: A guide to resources. Math and science partnership-motivation assessment program. University of Michigan, Ann Arbor, MI.

Van Der Krogt, F. and J. Warmerdam, 1997. Training in different types of organizations: Differences and dynamics in the organization of learning at work. Int. J. Human Resour. Manag., 8: 87-105. 
Villegas-Reimers, E., 2003. Teacher Professional Development: An International Review of the Literature. International Institute for Educational Planning, Paris.

Weimer, M., 2012. Five Characteristics of Learner-Centered Teaching. Magna Publications, Madison.

Wenglinsky, H. and S.C. Silverstein, 2007. The science training teachers need. Edu. Leadership, 64: 24-29.

Wenglinsky, H., 2001. Teacher Classroom Practices and Student Performance: How Schools Can Make a Difference. Educational Testing Service, Princeton, New Jersey.
Whitehead, J., 2009. Self-study, living educational theories and the generation of educational knowledge. Stud. Teacher Edu.: J. Self-Study Teacher Edu. Pract., 5: 107-111.

Zhu, C., D. Wang, Y.H. Cai and N. Engels, 2013. What core competencies are related to teachers' innovative teaching? Asia-Pacific J. Teacher Edu., 41: 9-27. 